\title{
The Mediating Role of Group Lending between Poverty and Microfinance
}

\begin{abstract}
${ }^{1}$ Saif-Ul-Mujahid Shah, ${ }^{2}$ Mujib Ur Rahman, ${ }^{3}$ Junaid Athar Khan
${ }^{1}$ Faculty of Economics and Business, University of Malaysia, Sarawak

${ }^{2}$ Demonstratorr, Department of Economics, Abdul Wali Khan University Mardan

${ }^{3}$ Assistant Professor Department of Management Sciences, Abdul Wali Khan University Mardan

\section{A B S T R A C T}

Microfinance has become the main tool of poverty alleviation in the 21 st century. The microfinance program in different countries has different lending approaches. The most common in the world is group lending and individual lending. Each lending procedure has its own merits and demerits. The present research is about the evaluation of the mediating role of group lending between microfinance and poverty. In this regard, the study was carried out in district Chitral. The data was collected from two local support organizations using a structured questionnaire. For the purpose of analysis structural equation modeling was used and Smart PLS was used as an analysis tool. The finding of the results shows that the group leaders have a positive role in the in mediating the relationship between microfinance and poverty and in reducing the moral hazards and proper utilization of funds.
\end{abstract}

Keywords: Microfinance, Group Lending, Individual Lending, Structural Equation Modelling

\section{INTRODUCTION}

Microfinance has become a powerful tool in the 21st century especially in developing countries to alleviate poverty (Lumianski, 2019). From the last three decades, the microfinance industry has not only expended but also has become the main tool of providing credit to the poor masses (Ledgerwood \& Gibson, 2013). The UN declaring of 2005 as a year of microfinance and awarding Noble prize to Muhammed Youns in 2006 for the Graeem Bank, the popularity of microfinance increased around the globe (Miled 
$\&$ Rejeb, 2015). The popularity can also be seen from the figures that in 1997, 13 million customers counted worldwide and by 2013, the total had hit 211 million (Morduch \& Cull, 2017; State of the Summit Report, 2015). Poverty has become a core issue in the socio-economic development of every nation (Jaffery \& Mamoon, 2015) and with the passage of time various initiatives have been undertaken worldwide to combat poverty. In this regard, United Nations also initiated the Sustainable Development Goals in order to reduce the poverty level all around the globe till 2030 (United Nations, 2017) and to achieve the goal, the United Nation considers microfinance as a unique tool and an easy access to the financial needs of the poor (Sfhea et al., 2017). According to the founder of Grameem bank, Yunus (2016), in most developing countries the basic cause of poverty is the lack finical access to the poor community and through microfinance, the financial access of the poor can be improved.

\section{LITERATURE REVIEW}

Microfinance organization have different procedures of lending loan to the poor people (Nordin et al., 2019), ranging from village bank, individual lending and group lending but the common approaches of lending money to the poor people are group and individual lending ( $\mathrm{Xu}$ et al., 2019) and in most of the developing nations the microfinance organization prefer the group lending approach as it creates a substitute for asset collateral (Mosley,1986; Udry, 1990). In addition, group lending approach mitigates moral hazard, adverse selection and debt enforcement problems (Besley \& Coate, 1995; Morduch, 1999; Ghatak, 1999; Ahlin \& Waters, 2011; Postelnicu et al., 2014; Yiwen \& Guangwen, 2016; Simmons \& Tantisantiwong, 2018). Moreover, in comparison to the individual lending approach, the loans are granted at lower interest rates in group lending design (Stiglitz, 1990; Besley \& Coate, 1995; Ghatak \& Guinnane, 1999; Armendariz de Aghion, 1999; Ghatak, 2000; Karlan, 2005).

Previous studies mostly have focused more on the effectiveness of the microfinance on poverty alleviations (Khavul et al., 2013; Vaessen et al., 2014; Roodman \& Morduch, 2014; Banerjee et al., 2015; Chliova et al., 2015; Attanasio et al., 2015; Crépon et al., 2015; Bandiera et al., 2016; McKenzie, 2016; Cai et al., 2016; Zhang, 
2017). Limited researches have been done on the delivery mechanisms of microfinance organizations such as individual lending or group lending (Besley \& Coate, 1995, Stiglitz, 1990; Ahlin \& Townsend, 2007; Giné et al., 2010; Ahlin, 2018; Modisagae, \& Ackermann, 2018). Moreover, their exit contradiction among the existing studies about the significance impact of the lending approaches as some are in favor and consider the lending approaches as positive effects on the loan default and increase in the loan repayment rate (Stiglitz \& Weiss, 1981; Ghatak \& Guinnane, 1999; Al-Azzam \& Mimouni, 2012; Carpena et al., 2013; Giné \& Karlan, 2014; Mahmud, 2015; Xing \& Xue, 2019). While in contrary there are some scholars that have reported negative impact of the microfinance organizations lending approaches on poverty alleviation (Waelde, 2011; Al-Azzam et al., 2012; Nghiem et al., 2012; Fischer, 2013; Gine and Karlan, 2014; Attanasio et al., 2015; Banerjee et al., 2015; De Quidt et al., 2017; Omolo, 2018; Nkwocha, et al., 2019). In light of the above inconclusive and limited research, the current research seeks to find the mediation effect of group lending on poverty in the Northern Areas of Pakistan.

\subsection{Hypothesis Development}

Group lending plays an important role in the effectiveness of microfinance on poverty alleviation (Khan \& Rahaman, 2007). The group-lending approach helps to select such individuals that lack financial resources and have the ability to use the loan productively (Schurmann \& Johnston 2009). In addition, previous studies confirm group lending approach as a strong tool of delivering loans to the deserving masses in developing countries (Khandker and Pitt, 1998; Khandker, 2005; Kaboski and Townsend 2005; Karlan and Zinman 2011; Annim and Alnaa, 2013; Attanasio et al., 2015). Dadson et al. (2012) study in Ghana reveals a positive impact on the group lending on respondent's income as compared to the control group. The same results were also observed by Annim and Alnaa (2013). In Indonesia, Takahashi et al. (2010) investigated the impact of group lending which evidenced significant impacts on respondents' expenditures. In addition, Al-Mamun et al. (2012) conducted research in Malaysia on group lending and found a significant impact on poverty reduction. In the same line, Crepon et al. (2011) studied the group lending approach in rural Morocco and observed 
that the group-based microfinance organizations had more impact on poverty as compared to other lending methodologies. Thus, the following hypothesis is developed.

$\boldsymbol{H}_{1}$ : Group lending mediates the relationship between microfinance and poverty.

\section{RESEARCH METHODOLOGY}

Data were collected from two local NGOs in Northern Areas of Pakistan. The Sample mostly consisted of females $60 \%$ and $30 \%$ male. The responses from the beneficiaries were collected through a 5 scale Likert questionnaire. This study employed Partial Least Squares (PLS) path modeling to test the hypothesis. Partial least squares structural equation modeling (PLS-SEM) is a variance-based structural equation modeling. This technique is used to model latent variables, specifically for composites, and the relationships between them (Henseler, 2017)

\subsection{Results of the Measurement Models}

Table 1 depicts the measurement models. Indicator loadings are in the range of 0.4 to .7 which satisfy the criteria (Hair et al., 2018; Ringle, et al., 2018). Likewise, the composite reliability is also met as all the latent values have a value greater than .70 (Fornnel \& Larcker, 1981) which shows that latent variables are internally consistent. In addition, the table also shows the average variance extracted from the variables has a value greater than the threshold value of .50 (Hair et al., 2019)

Table 1: Loadings, composite Reliability, and Average Variance Extracted

\begin{tabular}{|l|c|c|c|c|}
\hline Construct & Loading & CR & AVE & Convergent Validity \\
\hline Assets & $0.612-0.919$ & 0.905 & 0.659 & YES \\
\hline Education & $0.582-0.894$ & 0.853 & 0.598 & YES \\
\hline Effective & $0.579-0.888$ & 0.827 & 0.554 & YES \\
\hline Employment & $0.573-0.946$ & 0.911 & 0.681 & YES \\
\hline Expenditure & $0.585-0.934$ & 0.939 & 0.614 & YES \\
\hline Empowerment & $0.691-0.879$ & 0.903 & 0.610 & YES \\
\hline Health & $0.618-0.970$ & 0.943 & 0.773 & YES \\
\hline Income & $0.794-0.845$ & 0.933 & 0.665 & YES \\
\hline Interest & $0.609-0.908$ & 0.906 & 0.662 & YES \\
\hline Peer pressure & $0.69-0.887$ & 0.906 & 0.659 & YES \\
\hline Saving & $0.878-0.956$ & 0.964 & 0.841 & YES \\
\hline Social Ties & $0.528-0.924$ & 0.891 & 0.681 & YES \\
\hline Supervision & $0.653-0.922$ & 0.888 & 0.618 & YES \\
\hline Trust & $0.866-0.938$ & 0.945 & 0.811 & YES \\
\hline Loan Size & $0.849-0.961$ & 0.965 & 0.82 & YES \\
\hline
\end{tabular}




\subsection{Discriminant Validity}

Technically defined, Discriminant Validity is the extent to which a latent variable is different from other latent variables (Hair et al., 2014). The discriminant validity is examined through the Heterotrait-Monotrait ratio of correlations which recommends that values of the latent should not exceed .090 (Henseler et al., 2015). Table 2 depicts the discriminant validity test.

\begin{tabular}{|c|c|c|c|c|c|c|c|c|c|c|c|c|c|c|c|}
\hline Variables & Asset & Edu & Effect & Emply & Empov & Exp & Health & incm & Interest & Loan $\mathrm{Sz}$ & Pressure & Sav & Superv & Trust & Social \\
\hline \multicolumn{16}{|l|}{ Asset } \\
\hline Edu & 0.839 & & & & & & & & & & & & & & \\
\hline Effect & 0.607 & 0.472 & & & & & & & & & & & & & \\
\hline Employ & 0.637 & 0.877 & 0.334 & & & & & & & & & & & & \\
\hline Empov & 0.618 & 0.744 & 0.253 & 0.693 & & & & & & & & & & & \\
\hline Exp & 0.888 & 0.792 & 0.471 & 0.734 & 0.658 & & & & & & & & & & \\
\hline Health & 0.845 & 0.821 & 0.371 & 0.809 & 0.688 & 0.795 & & & & & & & & & \\
\hline Incm & 0.456 & 0.293 & 0.157 & 0.191 & 0.441 & 0.416 & 0.39 & & & & & & & & \\
\hline Interest & 0.531 & 0.322 & 0.886 & 0.267 & 0.15 & 0.396 & 0.337 & 0.306 & & & & & & & \\
\hline Loan Size & 0.461 & 0.306 & 0.734 & 0.231 & 0.132 & 0.259 & 0.229 & 0.188 & 0.897 & & & & & & \\
\hline Pressure & 0.812 & 0.543 & 0.514 & 0.513 & 0.404 & 0.737 & 0.683 & 0.358 & 0.509 & 0.336 & & & & & \\
\hline Sav & 0.792 & 0.655 & 0.351 & 0.541 & 0.516 & 0.721 & 0.716 & 0.417 & 0.491 & 0.401 & 0.668 & & & & \\
\hline Superv & 0.567 & 0.445 & 0.746 & 0.26 & 0.191 & 0.429 & 0.331 & 0.344 & 0.821 & 0.866 & 0.481 & 0.438 & & & \\
\hline Trust & 0.677 & 0.526 & 0.37 & 0.536 & 0.469 & 0.612 & 0.705 & 0.231 & 0.275 & 0.19 & 0.877 & 0.602 & 0.219 & & \\
\hline social & 0.653 & 0.614 & 0.423 & 0.504 & 0.414 & 0.575 & 0.58 & 0.213 & 0.319 & 0.176 & 0.852 & 0.58 & 0.234 & 0.749 & \\
\hline
\end{tabular}

\subsection{Results of Structural Model}

The results of the structural model are presented in Table 3. The table shows the structural relationships of the variables examined on the basis of the hypotheses.

\begin{tabular}{|l|l|c|c|c|}
\hline Table 3: Path Coefficients & Beta & SD & T-Statistics & P-Value \\
\hline Microfinance -> Group Lending & 0.769 & 0.023 & 33.836 & 0 \\
\hline Group Lending -> Poverty & 0.683 & 0.074 & 9.181 & 0 \\
\hline Microfinance -> Poverty & 0.095 & 0.079 & 1.194 & 0.233 \\
\hline
\end{tabular}




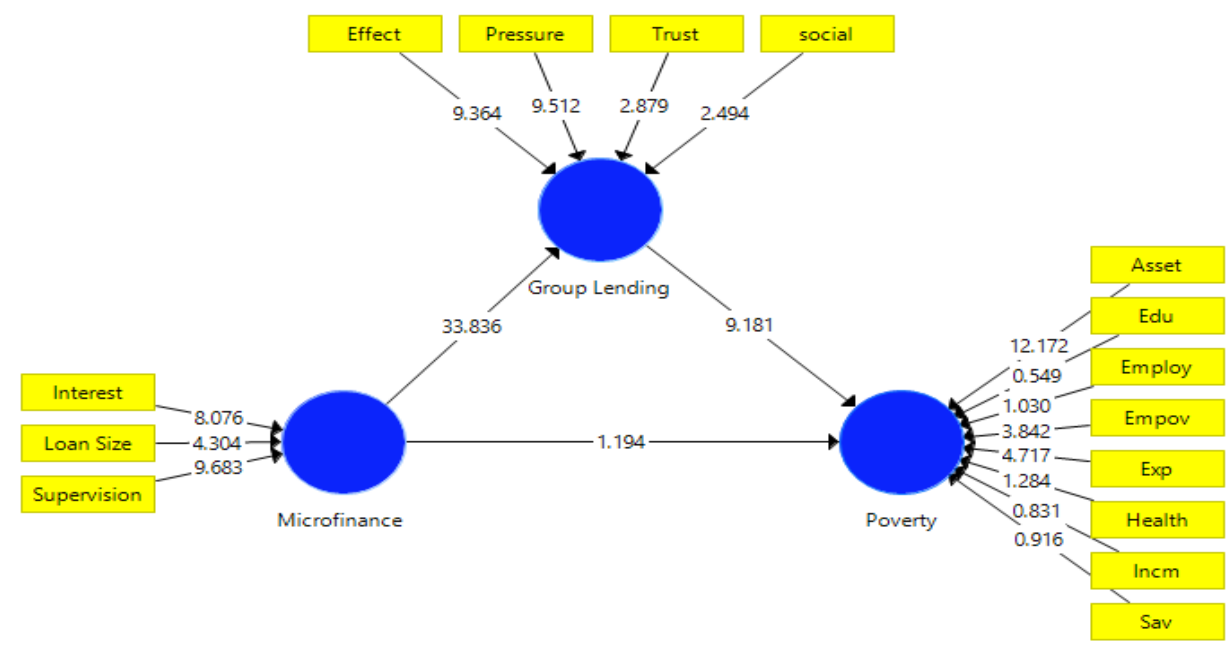

Figure 1. Structural model: Group lending as a mediating role between microfinance and poverty

The results of the structural model show full mediation as per the criteria of Baron and Kenny (1986). In order to have a full mediation, there should be no significant relationship between the independent variable and the dependent variable in the presence of the mediator variable. Thus, the current results are in the same line with the Baron and Kenny theory where a significant and positive relationship is observed between microfinance and group lending, $b=0.769, \mathrm{t}$ value $=3.973$. Furthermore, a significant positive link between group lending and poverty $(b=0.683, \mathrm{t}$ value $=9.181$, $\mathrm{p}$-value $=$ .000). In addition, the Sobel test was carried out to further ascertain the strength of the mediating effect and the results of the Sobel test also confirm the significant mediating effect $(\mathrm{t}=8.96, \mathrm{P}<0.00)$

\section{CONCLUSION}

The study investigated the mediating role of group lending on microfinance and poverty. The results of the structural equation model revealed that group lending has a significant positive impact on poverty and microfinance. Moreover, the lending approach plays an important role in the distribution of funds to the poor and preventing from the 
moral hazard, adverse selection problems strong. In addition, the social ties among the beneficiaries help in terms of screening, monitoring, and enforcement of payment of the loan on time. The study findings are consistent with the past literature (Kaboski \& Townsend 2005; Karlan \& Zinman 2011; Annim \& Alnaa, 2013; Postelnicu et al., 2014; Yiwen \& Guangwen, 2016). The poverty is measured on the base of socio and economic indicators while the microfinance indicators were loan size, interest and supervision. The overall result shows a positive impact on group lending on poverty.

\subsection{Future Direction}

Comprehensive research is a need in terms of the approaches so that one can adopt the best lending approach in the future for their microfinance projects. Furthermore, one should investigate the factors of defaulting by collateral lending groups in microfinance.

\section{REFERENCES}

Ahlin, C. (2019). Group Lending, Matching Patterns, and the Mystery of Microcredit: Evidence from Thailand. Retrieved https://qeconomics.org/ojs/forth/1115/1115-2.pdf

Ahlin, C. and Townsend, R. M. (2007). Using Repayment Data to Test Across Models of Joint Liability Lending. Economic Journal, 117(517), F11-F51.

Ahlin, C., \& Townsend, R. M. (2008). Selection into and across credit contracts: Theory and field research. Journal of Econometrics 13(6), 665-698.

Ahlin, C., \& Waters, B. (2009). Dynamic lending vs. group lending in the Ghatak/Stiglitz/Weiss adverse selection model. Mimeo.

Al-Azzam, M. \& Mimouni, K. (2012). 'What Types of Social Ties Improve Repayment in Group Lending?', International Research Journal of Finance and Economics, 8(7). 25-32.

Al-Azzam, M., Carter, H.R., \& Sarangi, S. (2012). 'Repayment Performance in Group Lending: Evidence from Jordan. Journal of Development Economics, 97(2), 404414.

Al-Mamun, A., C.A. Malarvizhi, S. Hossain, and S. Tan (2012). 'Examining the Effect of Microcredit on Poverty in Malaysia'. ASEAN Economic Bulletin, 29(1), 15-28.

Armendariz de Aghion, B., (1999). On the design of a credit agreement with peer monitoring". Journal of Development Economics 6(1), 79-104.

Attanasio, O., Augsburg, B., De Haas, R., Fitzsimons, E., \& Harmgart, H. (2015). 'The Impacts of Microfinance: Evidence from Joint-liability Lending in Mongolia'. American Economic Journal: Applied Economics, 7(1): 90-122.

Banerjee, A., Breza, E., Duflo, E., and Kinnan, C. (2015). Do credit constraints limit entrepreneurship? Heterogeneity in the returns to microfinance. Working Paper, Northwestern University, Chicago, IL, USA. http://faculty.wcas.northwestern.edu/ cgk281/ credit_entrepreneurship.pdf.

Baron, R. M., and Kenny, D. A. (1986), "The Moderator-Mediator Variable Distinction in 
Social Psychological Research: Conceptual, Strategic and Statistical Considerations", Journal of Personality and Social Psychology, 51(6), 11731182.

Besley, T., \& Coate, S. (1995). Group lending, repayment incentives, and social collateral. Journal of development economics, 46(1), 1-18

Cai, S., Park, A., \& Wang, S. (2016). "Microfinance Can Raise Incomes: Evidence from a Randomized Control Trial in China." Hong Kong University of Science and Technology, mimeo

Carpena, F., Cole, S., Shapiro, J., and Zia, B. (2013). Liability Structure in Small-Scale Finance: Evidence from a Natural Experiment. World Bank Economic Review, 27(3), 437-469.

Chliova, M., Brinckmann, J., and Rosenbusch, N. (2015). Is microcredit a blessing for the poor? A meta-analysis examining development outcomes and contextual considerations. Journal of Business Venturing, 30(3), 467-487.

Coleman, B. E. (2006). "Microfinance in Northeast Thailand: Who Benefits and How Much?" World Development 34(9), 1612-1638

Crépon, B., Devoto, F., Duflo, E., \& Parienté, W. (2015). "Estimating the Impact of Microcredit on Those Who Take It Up: Evidence from a Randomized Experiment in Morocco." American Economic Journal: Applied Economics, 7(1), 123- 150

Awunyo-Vitor, D., Abankwah, V., \& Kwansah, J. K. K. (2012). 'Women Participation in Microcredit and Its Impact on Income: A Study of Small-Scale Businesses in the Central Region of Ghana'. American Journal of Experimental Agriculture, 2(3), 502-515.

De Quidt, J., Fetzer, T., \& Ghatak, M. (2018). Commercialization and the decline of joint liability microcredit. Journal of Development Economics, 134, 209-225.

Duvendack, M., R. Palmer-Jones, J.G. Copestake, L. Hooper, Y. Loke, and N. Rao (2011). 'What is the Evidence of the Impact of Microfinance on the Well-being of Poor People? Systematic Review'. London: EPPI-Centre, Social Science Research Unit, Institute of Education, University of London.

Fischer, G. (2013). Contract Structure, Risk Sharing, and Investment Choice. Econometrica, 81(3), 883-939.

Ghatak, M., \& Guinnane, T. W. (1999). The economics of lending with joint liability: theory and practice. Journal of development economics, 60(1), 195-228.

Giné, X. and Karlan, D. (2014). Group Versus Individual Liability: Long-Term Evidence from Philippine Microcredit Lending Groups. Journal of Development Economics, 107(65-83).

Giné, X., Jakiela, P., Karlan, D., \& Morduch, J. (2010). Microfinance games. American Economic Journal: Applied Economics, 2(3), 60-95.

Giné, X., Karlan, D., \& Zinman, J. (2010). Put your money where your butt is: a commitment contract for smoking cessation. American Economic Journal: Applied Economics, 2(4), 213-35.

Hair Jr, J. F., Sarstedt, M., Ringle, C. M., \& Gudergan, S. P. (2018). Advanced issues in partial least squares structural equation modeling. Sage Publications.

Islam, A., Nguyen, C., \& Smyth, R. (2015). Does microfinance change informal lending in village economies? Evidence from Bangladesh. Journal of Banking \& Finance, 50, 141-156.

Jaffery, A., \& Mamoon, D. (2015). Socio-economic Perspective of Microfinance as a poverty reduction tool. Proceedings of 4th International Conference of Business Management. 
Karlan, D. S. (2007). Social connections and group banking. The Economic Journal, 117(517), F52-F84.

Khan, M. A., \& Rahaman, M. A. (2007). Impact of microfinance on living standards, empowerment and poverty alleviation of poor people: a case study on microfinance in the Chittagong District of Bangladesh.

Khandker, S. R. (2005). Microfinance and poverty: Evidence using panel data from Bangladesh. The World Bank Economic Review, 19(2), 263-286.

Khavul, S., Chavez, H., and Bruton, G. D. (2013). When institutional change outruns the change agent: The contested terrain of entrepreneurial microfinance for those in poverty. Journal of Business Venturing, 28(1), 30-50.

Ledgerwood, J., and A. Gibson (2013). 'The Evolving Financial Landscape'. In J. Ledgerwood (ed.), The New Microfinance Handbook. Washington, DC: The World Bank

Lumianski, E. (2019). A Review of Microfinance: What do we know?

McKenzie, D., \& Woodruff, C. (2008). Experimental evidence on returns to capital and access to finance in Mexico. The World Bank Economic Review, 22(3), 457-482.

Miled, K. B. H., \& Rejeb, J. E. B. (2015). Microfinance and poverty reduction: a review and synthesis of empirical evidence. Procedia-Social and Behavioral Sciences, 195, 705-712.

Modisagae, K., \& Ackermann, C. (2018). Determinants of defaulting by collateral lending groups in microfinancing: A probit regression approach. Acta Commercii, 18(1), $1-7$.

Morduch, J. (1999). The microfinance promise. Journal of economic literature, 37(4), 1569-1614.

Morduch, J. (2011). Why finance matters. Science, 332(6035), 1271-1272.

Morduch, J., \& Cull, R. (2017). Microfinance and Economic Development. In Handbook of Finance and Development. Edward Elgar Publishing.

Mosley, P. (1986). Risk, insurance and small farm credit in developing countries: A policy proposal. Public Administration and Development, 6(3), 309-319.

Mosley, P. (2001). Microfinance and poverty in Bolivia. Journal of Development Studies, 37(4), 101-132.

Nghiem, S., Coelli, T., and Rao, P. (2012). Assessing the welfare effects of microfinance in Vietnam: empirical results from a quasi-experimental survey. Journal of Development Studies, 48(5), 619-632.

Nkwocha, O. U., Hussain, J., El-Gohary, H., Edwards, D. J., \& Ovia, E. (2019). Dynamics of Group Lending Mechanism and the Role of Group Leaders in Developing Countries: Evidence from Nigeria. International Journal of Customer Relationship Marketing and Management (IJCRMM), 10(3), 54-71.

Niño-Zarazúa, M. (2007). 'The Impact of Microcredit on Income Poverty: An Endogeneitycorrected Estimation in Urban Mexico'. Sheffield Economic Research Paper Series. Sheffield: Department of Economics, University of Sheffield.

Nordin, N., Siti-Nabiha, A. K., \& Kamalia, Z. (2019). Microfinancing Influence on MicroEntrepreneurs Business Growth: Mediating Role of Psychological and Social Capital. Journal of Entrepreneurship, Business, and Economics, 7(2), 130-161.

Omolo, A. A. (2018). Lending model and loan repayment among financial institutions in kakamega municipality, kenya.

Postelnicu, L., Hermes, N., \& Szafarz, A. (2014). Defining social collateral in microfinance 
group lending. In Microfinance Institutions (pp. 187-207). Palgrave Macmillan, London.

Rasul, I., Bandiera, O., Burgess, R., Das, N., Gulesci, S., \& Sulaiman, M. (2016). "Labor Markets and Poverty in Village Economies." London School of Economics, working paper.

Ringle, C. M., Sarstedt, M., Mitchell, R., \& Gudergan, S. P. (2018). Partial least squares structural equation modeling in HRM research. The International Journal of Human Resource Management, 1-27.

Roodman, D. (2012). Due Diligence: An Impertinent Inquiry into Microfinance. Washington, DC: Center for Global Development.

Roodman, D., and Morduch, J. (2014). The impact of microcredit on the poor in Bangladesh: Revisiting the evidence. Journal of Development Studies, 50(4), 583-604.

Schurmann, A. T., \& Johnston, H. B. (2009). The group-lending model and social closure: microcredit, exclusion, and health in Bangladesh. Journal of health, population, and nutrition, 27(4), 518-529.

Sfhea, F., Ardisa, A., \& Ardisa, A. (2017). Microfinance for Poverty Alleviation: Do Transnational Initiatives Overlook Fundamental Questions of Competition, Informal Microcredit and Intermediation? Transnational Corporations, 24(3), 103117.

Sharma, M. \& Zeller, M. (1997). 'Repayment Performance in Group-Based Credit Programs in Bangladesh: An Empirical Analysis', World Development, 25(10), 1731-1742

Shaw, J. (2004). Microenterprise occupation and poverty reduction in microfinance programs: evidence from Sri Lanka. World Development, 32(7), 1247-1264.

Simmons, P., \& Tantisantiwong, N. (2018). Evaluation of individual and group lending under asymmetric information (Discussion Papers in Economics, 18/01) York. University of York 40pp

State of the Summit Report (2015). Report available at https://stateofthecampaign.org/data-reported/

Stewart, R., C. van Rooyen, K. Dickson, M. Majoro, and T. de Wet (2010). 'What is the Impact of Microfinance on Poor People? A Systematic Review of Evidence from Sub-Saharan Africa'. Technical report. London: EPPI-Centre, Social Science Research Unit, University of London.

Stiglitz, J. E. (1990). Peer monitoring and credit markets. The world bank economic review, 4(3), 351-366.

Stiglitz, J., and A. Weiss (1981). 'Credit Rationing in Markets with Imperfect Information'. American Economic Review, 71(3): 393-410.

Stiglitz, J., and A. Weiss (1983). 'Incentive Effects of Terminations: Applications to the Credit and Labor Markets'. American Economic Review, 73(5): 912-27.

Takahashi, K., Higashikata, T., \& Tsukada, K. (2010). The Short-Term Poverty Impact of Small-Scale, Collateral-Free Microcredit in Indonesia: A Matching Estimator Approach. The Developing Economies, 48(1), 128-155.

Udry, C. (1990). Credit markets in Northern Nigeria: Credit as insurance in a rural economy. The World Bank Economic Review, 4(3), 251-269.

United Nations. (2016). Sustainable Development Goals. Retrieved from United Nations: http://www.un.org/sustainabledevelopment/poverty/

United Nations (2017). United Nations Sustainable Development Goals (SDGs). https:// sustainabledevelopment.un.org/topics/sustainabledevelopmentgoals. 
Vaessen, J., Rivas, A., Duvendack, M., Jones, R. P., Van Gils, G., Lukach, R., \& Huband, $N$. (2014). The Effects of Microcredit on Women's Control over Household Spending in Developing Countries: A Systematic Review and Meta-analysis. Campbell Systematic Reviews, 10(1), 181-205.

World Health Organization (2016). Millennium Development Goals (MDGs). Retrieved from World Health Organization: http://www.who.int/topics/millennium_development_goals/about/en/

Xing, X., \& Xue, Y. (2019). Bogus Joint Liability Groups in Microfinance! Retrieved from http://www.sfu.ca/ akaraiva/KXX_current.pdf

$X u, Y$., Cheng, W., \& Zhang, L. (2019). Switching from group lending to individual lending: the experience at China's largest microfinance institution. Emerging Markets Finance and Trade, 1-18.

Yiwen, $T$ and Guangwen, H., (2016). The advantages and disadvantages of group lending and their solutions. Journal of Business and Economic Management 4(1), 009-016

Yunus, M. (2016). Nobel Lecture. Oslo, Norway.

Zhang, Q. (2017). Does microfinance reduce poverty? Some international evidence. The BE Journal of Macroeconomics, 17(2), 1-13. 